\title{
Establishment of growth medium and quantification of pollen grains and germination of pear tree cultivars ${ }^{1}$
}

\author{
Estabelecimento de meio de cultura e quantificação da quantidade de grãos de pólen e \\ germinação entre cultivares de pereiras
}

\author{
Paulyene Vieira Nogueira ${ }^{2}$, Givago Coutinho², Rafael Pio $^{3}$, Daniel Fernandes da Silva ${ }^{4}$ and Carolina Ruiz \\ Zambon $^{4 *}$
}

\begin{abstract}
To support breeding programs of pear tree, on the selection of cultivars to subtropical area in Brazil, the objective of this research was to adjust the growth medium basic to pollen grain germination. The pollen grains of 'D'Água' cultivar were spread on the surface of Petri dishes containing $20 \mathrm{ml}$ of culture medium in accordance with the following sequential experiments: 1$)$ ágar $\left(4 ; 6 ; 8\right.$ and $\left.10 \mathrm{~g} \mathrm{~L}^{-1}\right)$ and $\mathrm{pH}(3,5 ; 4,5 ; 5,5$ and 6,5$\left.) ; 2\right)$ sucrose $\left(0 ; 30 ; 60\right.$ and $\left.\left.90 \mathrm{~g} \mathrm{~L}^{-1}\right) ; 3\right)$ calcium nitrate $\left(0 ; 200 ; 400\right.$ and $\left.\left.800 \mathrm{mg} \mathrm{L}^{-1}\right) ; 4\right)$ boric acid $\left(0 ; 400 ; 800\right.$ and $\left.\left.1200 \mathrm{mg} \mathrm{L}^{-1}\right) ; 5\right)$ temperature of incubation $\left(15 ; 20 ; 25\right.$ e $\left.30{ }^{\circ} \mathrm{C}\right)$ and 6$)$ emission time of the pollen tube $(0 ; 1 ; 2 ; 3 ; 4 ; 5$ and 6 hours after inoculation). After incubation, the germination rate of pollen grains of nine pear cultivars ('Rocha', 'Abate Fetel', 'Packham's Triumph', 'Atago', 'Hosui', 'Primorosa', 'Triunfo', 'Seleta' and 'D'Água') was evaluated, and number of stamens, the number of pollen grains per anther and per flower. The protocol for germination of pollen grains of pear tree consist in the culture medium have to be solidified with $10 \mathrm{~g} \mathrm{~L}^{-1}$ ágar, being the $\mathrm{pH}$ measured to 5,2, added with $90 \mathrm{~g} \mathrm{~L}^{-1}$ sucrose, $145 \mathrm{mg} \mathrm{L}^{-1}$ calcium nitrate and $700 \mathrm{mg} \mathrm{L}^{-1}$ boric acid, with incubation temperature of $23{ }^{\circ} \mathrm{C}$. The readings germination percentage should be performed after five hours of incubation. The pollen grain 'Rocha' cultivar showed higher germination percentage.
\end{abstract}

Key words: Pyrus communis. Pyrus pyrifolia. Breeding programs. Germination rate.

\begin{abstract}
RESUMO - Visando dar suporte aos trabalhos de melhoramento da pereira, para seleção de cultivares para regiões subtropicais, objetivou-se ajustar o meio de cultura para a germinação de grãos de pólen. Os grãos de pólen da cultivar 'D'Água' foram espalhados sobre placas de Petri contendo $20 \mathrm{~mL}$ de meio, de acordo com os experimentos sequenciais: 1) ágar (4; 6; 8 e $\left.10 \mathrm{~g} \mathrm{~L}^{-1}\right)$ e pH $(3,5 ; 4,5 ; 5,5$ e 6,5); 2) sacarose (0; 30; 60 e $\left.90 \mathrm{~g} \mathrm{~L}^{-1}\right) ; 3$ ) nitrato de cálcio $\left(0 ; 200 ; 400\right.$ e $\left.\left.800 \mathrm{mg} \mathrm{L}^{-1}\right) ; 4\right)$ ácido bórico $\left(0 ; 400 ; 800\right.$ e $\left.\left.1200 \mathrm{mg} \mathrm{L}^{-1}\right) ; 5\right)$ temperatura de incubação $\left(15 ; 20 ; 25\right.$ e $\left.30^{\circ} \mathrm{C}\right)$ e 6$)$ tempo de emissão do tubo polínico $(0 ; 1 ; 2 ; 3 ; 4 ; 5$ e 6 horas após a inoculação). Após a inoculação avaliou-se a germinação dos grãos de pólen de nove cultivares ('Rocha', 'Abate Fetel', 'Packham's Triumph', 'Atago', 'Hosui', 'Primorosa', 'Triunfo', 'Seleta' e 'D'Água'), além do número de anteras, número de grãos de pólen por antera e por flor. O protocolo para germinação de grãos de pólen de pereira consiste no meio de cultura ser solidificado com $10 \mathrm{~g} \mathrm{~L}^{-1}$ de ágar, com pH ideal de 5,2, acrescido de $90 \mathrm{~g} \mathrm{~L}^{-1}$ de sacarose, $145 \mathrm{mg} \mathrm{L}^{-1}$ de nitrato de cálcio e $700 \mathrm{mg} \mathrm{L}^{-1}$ de ácido bórico, com temperatura de incubação de $23,7^{\circ} \mathrm{C}$. As análises de germinação devem ser realizadas após 5 h de incubação. Os grãos de pólen da cultivar 'Rocha' apresentaram maior porcentagem de germinação.
\end{abstract}

Palavras-chave: Pyrus communis. Pyrus pyrifolia. Melhoramento genético. Taxa de germinação.

\footnotetext{
DOI: $10.5935 / 1806-6690.20160045$

*Autor para correspondência

${ }^{1}$ Recebido para publicação em 22/09/2014; aprovado em 19/01/2016

Extraído da Tese de Doutorado do primeiro autor, defendida no Programa de Pós-Graduação em Botânica Aplicada da Universidade Federal de Lavras/UFLA ${ }^{2}$ Programa de Pós-Graduação em Agronomia/Fitotecnia, Departamento de Agricultura, Universidade Federal de Lavras/UFLA, Caixa Postal 3.037, Lavras-MG, Brasil, 37.200-000, paulyene@gmail.com, givago_agro@ hotmail.com

${ }^{3}$ Departamento de Agricultura, Universidade Federal de Lavras/UFLA, Caixa Postal 3.037, Lavras-MG, Brasil, 37.200-000, rafaelpio@ dag.ufla.br

${ }^{4}$ Programa de Pós-Graduação em Botânica Aplicada, Departamento de Biologia, Universidade Federal de Lavras/UFLA, Caixa Postal 3.037, Lavras-MG,

Brasil,37.200-000, daniel_eafi@yahoo.com.br, carolzambon@posgrad.ufla.br
} 


\section{INTRODUCTION}

The production of pears in Brazil is fairly insignificant, being around 20,000 t per year. However, consumption is approximately eight times greater than the total produced, which makes the country one of the world's leading importers of this fruit (FACHINELLO et al., 2011).

Despite the pear being a fruit from temperate climates, there are some cultivars adapted to a subtropical climate (BETTIOL NETO et al., 2014; TECCHIO et al., 2011); the cultivation of this fruit in regions with mild winters is possible due to hybrid cultivars (Pyrus communis x P. pyrifolia) known as hardy pears. These cultivars were obtained by hybridisation between European pears (high winter cold requirement and excellent fruit quality) and oriental pears (low winter cold requirement and inferior fruit quality), developed in past decades by the Campinas Agronomic Institute (BARBOSA et al., 2007, BETTIOL NETO et al., 2014;. SEIFERT et al., 2009). However, due to increased imports of higher quality pears like 'Rocha' and 'Abate Fetel', breeding programs need to be improved in order to obtain better quality cultivars adapted to the subtropical conditions of Brazil. If this is so, the most sensible strategy in programs for genetic improvement of the pear in regions with mild winters, which seek the quality of European pears with the lower cold requirement of Asian pears (BARBOSA et al., 2007), would be to use the cultivar Packham's Triumph as one of the parent plants, as this has a lower cold requirement compared to other European pears (BARBOSA et al., 2008). However, to select this cultivar as the male parent, it needs to produce viable pollen grains in high quantities; this information is not found in the literature.

To support pear breeding programs, it is necessary to know the floral characteristics of the plants to be used as parents, so as to choose which cultivars should be used in hybridisation, an indispensable precondition for achieving good results in crossings between parents (BARBOSA et al., 2010; CHAGAS et al., 2009). Reis et al. (2011) refer to the technique of germination in vitro as giving results which are closer to those which probably occur in vivo.

Various organic and inorganic compounds interfere with pollen germination in vitro, of which agar, sucrose, calcium and boron are the most important. Figueiredo et al. (2013) point out that boric acid is essential to the germination of pollen grains. The $\mathrm{pH}$ of the culture medium also influences the germination and viability of the pollen grains (RAMOS et al., 2008), and factors such as temperature and incubation time are likewise important in this process (CHAGAS et al., 2010).
There is therefore a need to establish a culture medium protocol, which can be used in the test for the germination capacity of pollen grains in the pear. As the amount of pollen grains per flower can vary between cultivars (ZAMBON et al., 2014), this factor is also important, as it has a direct effect on the number of pollinated flowers and consequently on productivity.

This study aimed to establish a culture medium protocol for in vitro germination of pollen grains in pear cultivars, compare cultivars in relation to pollen fertility, and further, quantify the number of anthers, and the number of pollen grains per anther and per flower.

\section{MATERIAL AND METHODS}

The study was carried out between July and September of 2014, using nine pear cultivars of four years of age. The cultivars used in the experiment were: Rocha, Abate Fetel, Packham's Triumph, Atago, Hosui, Primorosa, Triunfo, Seleta and D'Água.

The work was divided into three parts: establishing a protocol for in vitro pollen germination, a test for pollen germination between cultivars, and quantification of the pollen grains per anther and per flower.

\section{Establishing a protocol for in vitro pollen germination}

The D’Água cultivar was used to establish a culture medium due to its early flowering in relation to the other cultivars. The anthers were removed from ten flower buds collected in the late afternoon using tweezers, and stored in open petri dishes at a controlled temperature $\left(27^{\circ} \mathrm{C}\right)$ for 12 hours, so that anthesis could take place, together with complete dehiscence, and release of the pollen grains (RAMOS et al., 2008).

After collecting the pollen grains of the 'D'Água' cultivar, the following experiments were conducted:

1. Concentration of agar $\left(4,6,8\right.$ and $\left.10 \mathrm{~g} \mathrm{~L}^{-1}\right)$, and $\mathrm{pH}$ of the medium $(3.5,4.5,5.5$ and 6.5$)$;

2. Concentration of sucrose $\left(0,30,60\right.$ and $\left.90 \mathrm{~g} \mathrm{~L}^{-1}\right)$;

3. Concentration of calcium nitrate - $\mathrm{Ca}\left(\mathrm{NO}_{3}\right)_{2}(0,200,400$ and $800 \mathrm{mg} \mathrm{L}^{-1}$ );

4. Concentration of boric acid (0, 400, 800 and $\left.1200 \mathrm{mg} \mathrm{L}^{-1}\right)$;

5. Incubation temperature $\left(15,20,25\right.$ and $\left.30^{\circ} \mathrm{C}\right)$; and

6. Pollen tube emission time $(0,1,2,3,4,5$ and 6 hours after inoculation).

Determination of the culture medium protocol was performed sequentially (experiments 1-6), always using the best result from the previous experiment to set up the subsequent treatment, as per Chagas et al. (2010). 
With the aid of a brush, pollen was spread along the surface of the petri dish containing $20 \mathrm{ml}$ of culture medium, always seeking a uniform distribution across the surface of the medium. The dishes were then capped and stored in the absence of light. Four hours after inoculation, the pollen grains were viewed under a monocular microscope with a 10x objective to quantify the germinated pollen grains.

A pollen grain was considered germinated where the length of the pollen tube exceeded twice its own diameter (CHAGAS et al., 2009). The experiments were conducted in a completely randomised design with four replications, each represented by one quadrant of the petri dish, and comprising the average from five fields of view.

\section{Test for pollen germination between cultivars}

After establishing the basic culture medium for the pear, the pollen grains from each of the nine cultivars were subjected to in vitro germination to evaluate germination capacity. The experiment was carried out in a completely randomised design, consisting of nine treatments, represented by the pear cultivars (Rocha, Abate Fetel, Packham's Triumph, Atago, Hosui, Primorosa, Triunfo, Seleta and D'Água) with four replications, each represented by one quadrant of the petri dish and consisting of the average from five fields of view.

\section{Quantification of pollen grains per anther and per flower}

In the experiment to determine the number of pollen grains per anther and per flower, twenty flower buds were collected from each cultivar, and the number of anthers per flower were counted. Five anthers were then separated at random, and each set of anthers stored in uncapped Eppendorf tubes at a controlled temperature $\left(27^{\circ} \mathrm{C}\right)$ for $24 \mathrm{~h}$ in the absence of light, for dehiscence to take place with the release of pollen grains (NOGUEIRA et al., 2015). After 24 hours, a solution of 1,000 $\mu$ l of lactic acid was added to the tube. After 48 hours, a sample of $10 \mu \mathrm{l}$ from each Eppendorf tube was placed on a test slide (Neubauer) for the number of pollen grains to be counted with the aid of an optical microscope (100x objective). The experiment was conducted with five replications, each replication consisting of four readings of the Neubauer slide.

The number of pollen grains per anther was calculated by multiplying the average number of pollen grains from each sample by the volume of lactic acid in the solution $(1.000 \mu \mathrm{l})$ and dividing this value by the product between the volume of lactic acid in the sample $(10 \mu \mathrm{l})$ and the number of anthers in each tube (five). The number of pollen grains per flower was calculated by multiplying the average estimate for pollen grains per anther by the average number of anthers per flower.

The data from all the experiments were subjected to analysis of variance, the quantitative mean values being subjected to linear or quadratic regression at $5 \%$ probability, and the qualitative averages evaluated using the Scott-Knott means grouping test. Analyses were carried out using the SISVAR software [Sistema para Análise de Variância] (FERREIRA, 2011).

\section{RESULTS AND DISCUSSION}

\section{Establishing a protocol for in vitro pollen germination}

No interaction was seen between the values for $\mathrm{pH}$ and the agar concentrations added to the culture medium. It was found that the lowest $\mathrm{pH}$ was unfavourable to germination, since at the $\mathrm{pH}$ of 3.5, only $9.68 \%$ germination was obtained, but with the $\mathrm{pH}$ adjusted to 5.2, maximum germination percentage was achieved (17.39\%) (Figure 1a). Ramos et al. (2008) stated that there is an increase in the germination of pollen grains in citrus plants with an increase in the $\mathrm{pH}$ of the culture medium.

With the agar variable, the greatest concentration used, of $10 \mathrm{~g} \mathrm{~L}^{-1}$, promoted the greatest germination of pollen grains (16.93\%) (Figure 1b); these results agree with other studies, such as that by Zambon et al. (2014), who noted a higher germination percentage in pollen grains from the quince for the same concentration of agar, and by Chagas et al. (2010), in pollen grains from rootstock of the Pyrus calleryana and P. betulaefolia pears.

One possible explanation for the highest germination percentage having occurred at the concentration of 10 $\mathrm{g}$ agar $\mathrm{L}^{-1}$, is that the high concentration of this gelling agent allowed greater consistency of the culture medium, promoting balance in the osmotic potential of the medium, thus favouring germination of the pollen grains. Furthermore, an important factor in the culture medium is that the $\mathrm{pH}$ be properly adjusted, as this directly influences solidification of the medium (CHAGAS et al., 2009).

With the addition of sucrose to the culture medium, an increase in germination percentage was seen for increases in the concentration of sucrose in the medium, with the greatest percentage for germination of pollen grains in the pear $(24.1 \%)$ being seen at a concentration of $90 \mathrm{~g} \mathrm{~L}^{-1}$ (Figure 1c). A linear increase in the germination percentage of pollen grains for increases in sucrose concentration was also found by Chagas et al. (2010), in studies carried out with pear rootstock, and by Figueiredo et al. (2013), with the blackberry (Rubus spp.). According to these authors, the effect of adding sucrose on the germination of pollen grains may be related to the supply of metabolic energy and carbon skeletons for the biosynthesis of organic compounds necessary for cell growth.

With the addition of different concentrations of calcium nitrate $\left[\mathrm{Ca}\left(\mathrm{NO}_{3}\right)_{2}\right]$ to the culture medium, it can be seen from breakdown of the equation in Figure 1d, that the 
concentration of $145 \mathrm{mg} \mathrm{L}^{-1}$ favoured $26.5 \%$ germination of the pollen grains, being however, an increase of only $0.57 \%$ germination compared to the control. Other authors report that calcium nitrate has no significant influence on increases in the germination percentage of pollen grains (CHAGAS et al., 2009; CHAGAS et al., 2010).

A marked increase in germination percentage of pollen grains in this work was obtained with the addition of boric acid to the culture medium. In the absence of boric acid, the germination percentage was $27.28 \%$. From breakdown of the equation in Figure 1e, it was found that the addition of $700 \mathrm{mg}$ boric acid $\mathrm{L}^{-1}$ to the medium resulted in the germination of $70.10 \%$ of the pollen grains, an increase of $42.82 \%$. The addition of boron was also beneficial to the germination of pollen grains from rootstock of the pear (CHAGAS et al., 2010) and the blackberry (FIGUEIREDO et al., 2013).

According to Xie et al. (2004) and Nava et al. (2009), boron is a fundamental element for the germination of pollen grains in rosaceae. According Franzon and Raseira (2006), boron stimulates growth of the pollen tube and reduces the possibility of the pollen splitting. This could be the reason for the significant increase in germination percentage of pollen grains in the pear.

Another explanation for the significant increase in germination percentage could be related to the formation of the ionisable sugar-borate complex, which reacts with the plasma membrane, promoting greater growth of the pollen tube (DANTAS et al., 2005). Probably, the addition of boron to the culture medium, with the subsequent formation of this complex, was beneficial during germination of the pollen grains in the pear, increasing germination percentage.

Among the temperatures being evaluated, it was seen that greatest rate of germination of the pollen grains took place when subjected to $23.7^{\circ} \mathrm{C}(71.34 \%)$ (Figure 1f). The temperature to which the pollen is exposed during the germination phase is directly related to development of the pollen tube. Very low temperatures result in a decrease in metabolic activity, preventing germination, while very high temperatures cause degradation of the proteins and enzymes essential for the development of the pollen tube (BRETON; BERVILLÉ, 2012; GALÁN et al., 2005). This was seen in the present work, since at a temperature of $15^{\circ} \mathrm{C}$, germination of the pollen grains was $32.01 \%$ : a decrease of $39.33 \%$ compared to the ideal temperature found; and at the temperature of $30{ }^{\circ} \mathrm{C}$, the germination of pollen grains in the pear was $49.12 \%$ : a decrease of $22.22 \%$ in relation to the ideal temperature $\left(23.7^{\circ} \mathrm{C}\right)$.

When the time required for pollen tube emission is measured, it can be seen that germination started one hour after inoculation, with the percentage of pollen grains that emitted a pollen tube increasing until around five hours after inoculation (79.64\% of germination); after this period, germination of the pollinia (coherent mass of pollen grains) in the culture medium stabilised (Figure 1g). According to Gaaliche et al. (2013), there is an increase in germination percentage of the pollen grains during the time of incubation.

It was established with this study that the protocol for pollen germination in the pear is $90 \mathrm{mg}$ sucrose $\mathrm{L}^{-1}, 145$ mg calcium nitrate $\mathrm{L}^{-1}, 700 \mathrm{mg}$ boric acid $\mathrm{L}^{-1}$ and $10 \mathrm{~g}$ agar $\mathrm{L}^{-1}$, at a $\mathrm{pH}$ of 5.2 and a temperature of $23.7^{\circ} \mathrm{C}$. Analyses should be made after 5 hours of incubation.

\section{Test for pollen germination between cultivars and Quantification of pollen grains per anther and per flower}

Statistical analysis of the results showed a significant difference between pear cultivars. The means grouping test placed the cultivars into four groups for germination percentage. Pollen grains from the Rocha cultivar had the highest germination percentage $(82.64 \%)$, followed by the cultivars D'Água $(71.09 \%)$ and Abate Fetel $(71.09 \%)$, then Atago (43.28\%), and the remainder with a germination percentage ranging from $11.16 \%$ to $27.07 \%$ (Table 1 ).

European cultivars of the species Pyrus communis (Rocha and Abate Fetel) displayed pollen grains of high germination capacity, except for the cultivar Packham's Triumph. Furthermore, hybrids between the European pears (Pyrus communis) and the Asian pears (Pyrus pyrifolia), the cultivars, Primorosa, Seleta and Triumph, displayed pollen grains of low germination capacity, having the cultivar Packham's Triumph as one of the parent plants (BARBOSA et al., 2008).

As for the number of anthers per flower, only the cultivars Packham's Triumph and Primorosa had lower values (Table 1). For the number of pollen grains per anther and per flower, the European cultivars of the species Pyrus communis (Rocha, Abate Fetel and Packham's Triumph), as well as D'Água, displayed higher values, ranging from 25,910.00 to $37,098.33$ pollen grains per flower (Table 1). The number of anthers varies between pear cultivars, and even between species, as also occurs with other rosaceae, as reported by Albuquerque Júnior et al. (2010) in the apple. Stanton et al. (2007), and Mello Júnior, Orth and Moretto (2011) point out that a larger number of anthers does not always indicate a greater amount of pollen grains per flower.

Cultivars with a large amount of pollen grains require fewer flowers for hybridisation in the field. For cultivars that present a lower rate of germination and a smaller amount of pollen grains per flower, one option would be their use as female parents (FIGUEIREDO et al., 2013). Perhaps this would be the most sensible strategy in breeding programs for the pear in regions 
Figure 1 - Germination percentage in vitro of pollen grains of the D'Água pear, subjected to different values for $\mathrm{pH}$ (a) and agar concentration in $\mathrm{g} \mathrm{L}^{-1}$ (b) of the culture medium, different concentrations of sucrose in $\mathrm{g} \mathrm{L}^{-1}$ (c), different concentrations of calcium nitrate in $\mathrm{mg} \mathrm{L}^{-1}(\mathrm{~d})$, different concentrations of boric acid in $\mathrm{mg} \mathrm{L}^{-1}(\mathrm{e})$, different temperatures (f) and different times of incubation $(\mathrm{g})$ for the germination of pollen grain
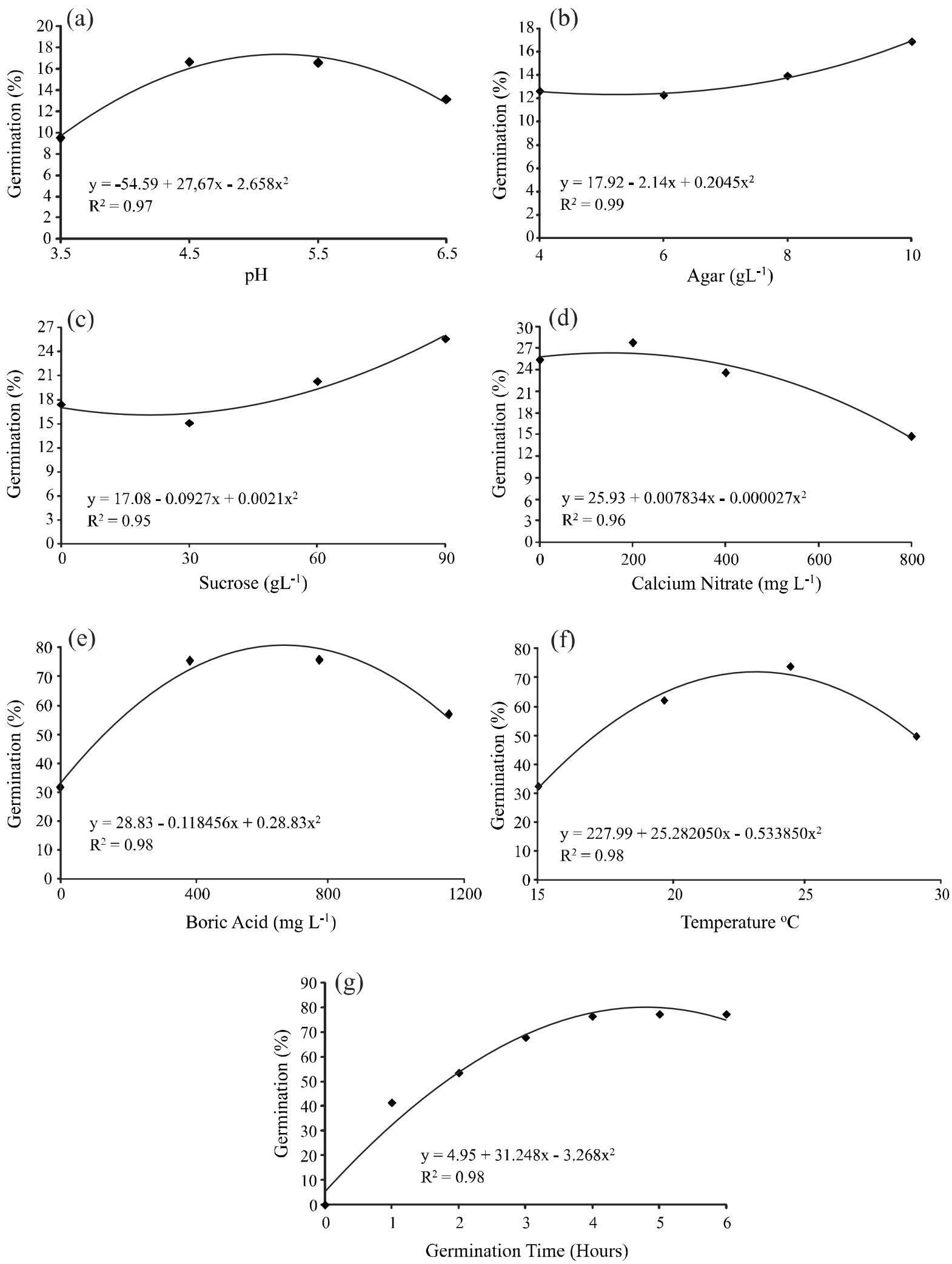
Table 1 - Mean values for germination, number of anthers per flower, number of pollen grains per anther and number of pollen grains per flower, for different pear cultivars

\begin{tabular}{lcccc}
\hline Cultivar & ${\text { Germination }(\%)^{(1)}}^{(}$ & Number of anthers per flower ${ }^{(1)}$ & Number of pollen grains per anther $^{(1)}$ & Number of pollen grains per flower $^{(1)}$ \\
\hline Rocha & $82.64 \mathrm{a}$ & $19.17 \mathrm{a}$ & $1,756.67 \mathrm{a}$ & $33,492.50 \mathrm{a}$ \\
Abate Fetel & $71.09 \mathrm{~b}$ & $18.67 \mathrm{a}$ & $1,768.33 \mathrm{a}$ & $25,910.00 \mathrm{a}$ \\
D'água & $72.77 \mathrm{~b}$ & $20.00 \mathrm{a}$ & $1,901.67 \mathrm{a}$ & $37,098.33 \mathrm{a}$ \\
Atago & $43.28 \mathrm{c}$ & $20.00 \mathrm{a}$ & $1,033.33 \mathrm{~b}$ & $20,736.67 \mathrm{~b}$ \\
Packham's Triumph & $27.07 \mathrm{~d}$ & $12.67 \mathrm{~b}$ & $2,116.67 \mathrm{a}$ & $26,746.67 \mathrm{a}$ \\
Triunfo & $22.54 \mathrm{~d}$ & $19.00 \mathrm{a}$ & $601.67 \mathrm{~b}$ & $11,429.17 \mathrm{~b}$ \\
Hosui & $19.42 \mathrm{~d}$ & $19.67 \mathrm{a}$ & $203.33 \mathrm{~b}$ & $4,015.83 \mathrm{c}$ \\
Seleta & $11.39 \mathrm{~d}$ & $18.17 \mathrm{a}$ & $983.33 \mathrm{~b}$ & $17,860.83 \mathrm{~b}$ \\
Primorosa & $11.16 \mathrm{~d}$ & $12.83 \mathrm{~b}$ & $1,001.67 \mathrm{~b}$ & $12,506.67 \mathrm{~b}$ \\
CV $(\%)$ & 27.46 & 8.25 & 30.45 & 31.06 \\
\hline
\end{tabular}

${ }^{(1)}$ Mean values followed by the same letter belong to the same group by Scott-Knott test $(\mathrm{p}>0.05)$

with mild winters, which seek the quality of European pears with the lower cold requirement of Asian pears (BARBOSA et al., 2007). As the cultivar Packham's Triumph, which has less cold requirement compared to other European pears (BARBOSA et al., 2008), has a large amount of pollen grains per anther and per flower, it could be used as the male parent, and the Asian Hosui pear, which has a smaller amount of pollen grains, as the female parent.

\section{CONCLUSIONS}

1. The culture medium should be increased by $90 \mathrm{~g}$ sucrose $\mathrm{L}^{-1}, 145 \mathrm{mg}$ calcium nitrate $\mathrm{L}^{-1}$ and $700 \mathrm{mg}$ boric acid $\mathrm{L}^{-1}$, the $\mathrm{pH}$ adjusted to 5.2, and the medium solidified with $10 \mathrm{~g}$ agar $\mathrm{L}^{-1}$. Readings to measure the germination of pollen grains in the pear should be taken after five hours of incubation;

2. Pollen grains of the cultivar Rocha, show a higher germination percentage compared to the other cultivars;

3. European pears of the species Pyrus communis (Rocha, Packham's Triumph and Abate Fetel) and D'Água have a larger quantity of pollen grains per flower and per anther compared to Asian and hybrid pears.

\section{REFERENCES}

ALBUQUERQUE JÚNIOR, C. L. et al. Número de anteras por flor, grãos de pólen por antera e capacidade germinativa do pólen de diferentes cultivares de macieiras. Revista Brasileira de Fruticultura, v. 32, n. 4, p. 1255-1260, 2010.

BARBOSA, W. et al. Advances in low-chilling peach breeding at Instituto Agronômico, São Paulo State, Brazil. Acta Horticulturae, v. 872, p. 147-150, 2010.
BARBOSA, W. et al. Asian pear breeding in brazil: characterization of new selections. Acta Horticulturae, v. 800, p. 503-506, 2008.

BARBOSA, W. et al. Asian pear tree breeding for subtropical areas of Brazil. Fruits, v. 62, n. 1, p. 1-6, 2007.

BETTIOL NETO, J. E. et al. Produção e qualidade póscolheita de cultivares de pereira nas condições subtropicais da região leste paulista. Ciência Rural, v. 44, n. 10, p. 17401746, 2014.

BRETON, C. M.; BERVILLÉ, A. New hypothesis elucidates self-incompatibility in the olive tree regarding S-alleles dominance relationships as in the sporophytic model. Comptes Rendus Biologies, v. 335, p. 563-572, 2012.

CHAGAS, E. A. et al. Composição do meio de cultura e condições ambientais para germinação de grãos de pólen de porta-enxertos de pereira. Ciência Rural, v. 40, n. 2, p. 261266, 2010.

CHAGAS, E. A. et al. Germinação in vitro de grãos de pólen de Prunus persica (L.) Batsch Vulgaris. Bioscience Journal, v. 25, n. 5 , p. 8-14, 2009.

DANTAS, A. C. M. et al. Viabilidade do pólen e desenvolvimento do tubo polínico em macieira (Malus spp.). Revista Brasileira de Fruticultura, v. 27, n. 3, p. 356-359, 2005.

FACHINELLO, J. C. et al. Situação e perspectivas da fruticultura de clima temperado no Brasil. Revista Brasileira de Fruticultura, v. 33, p. 109-120, 2011. Edição especial.

FERREIRA, D. F. Sisvar: a computer statistical analysis system. Ciência e Agrotecnologia, v. 35, n. 6, p. 1039-1042, 2011.

FIGUEIREDO, M. A. et al. Características florais e carpométricas e germinação in vitro de grãos de pólen 
de cultivares de amoreira-preta. Pesquisa Agropecuária Brasileira, v. 48, n. 7, p. 731-740, 2013.

FRANZON, R. C.; RASEIRA, M. C. B. Germinação in vitro e armazenamento do pólen de Eugenia involucrata DC (Myrtaceae). Revista Brasileira de Fruticultura, v. 28, n. 1, p. 18-20, 2006.

GAALICHE, B. et al. Assessment of pollen viability, germination, and tube growth in eight tunisian caprifig (Ficus carica L.) cultivars. ISRN Agronomy, n. 2013, p. 1-4, 2013.

GALÁN, C. et al. Heat requirement for the onset of the Olea europaea L. pollen season in several sites in Andalusia and the effect of the expected future climate change. International Journal of Biometeorology, v. 49, p. 184-188, 2005.

MELLO JÚNIOR, L. J.; ORTH, A. I.; MORETTO, G. Ecologia da polinização da amoreira-preta (Rubus sp.) (Rosaceae) em Timbó-SC, Brasil. Revista Brasileira de Fruticultura, v. 33, n. 3, p. 1015-1018, 2011.

NAVA, G. A et al. Fenologia e produção de pessegueiros 'granada' com aplicação de cianamida hidrogenada e boro. Revista Brasileira de Fruticultura, v. 31, n. 2, p. 297-304, 2009.

NOGUEIRA, P. V. et al. Germinação de pólen e aplicação de ácido bórico em botões florais de nespereiras. Bragantia, v. 74, n. 1, p. 9-15, 2015.
RAMOS, J. D. et al. Receptividade do estigma e ajuste de protocolo para germinação in vitro de grãos de pólen de citros. Interciência, v. 33, n. 1, p. 51-55, 2008

REIS, R. V. et al. Viabilidade in vitro de grãos de pólen de bananeira sob diferentes concentrações de ácido bórico e sacarose. Ciência e Agrotecnologia, v. 35, n. 3, p. 547-553, 2011.

SEIFERT, K. E. et al. Mudas de pera produzidas por dupla enxertia em marmeleiro utilizando o porta-enxerto 'Japonês'. Pesquisa Agropecuária Brasileira, v. 44, n. 12, p. 1631-1635, 2009.

STANTON, M. A. et al. Floral competence of primocane-fruiting blackberries prime-jan and prime-jim grown at three temperature regimens. HortScience, v. 42, n. 3, p. 508-513, 2007.

TECCHIO, M.A. et al. Evolution and perspective of the temperate fruit crops in São Paulo state, Brazil. Revista Brasileira de Fruticultura, v. 33, p. 150-157, 2011. Edição especial.

XIE, S. et al. Pollen viability of Asian pear and effect of PGR, $\mathrm{B}$ and sucrose on germination and pollen tube development. Jornal of Fruit Science, v. 1, n. 4, p. 289-294, 2004.

ZAMBON, C. R. et al. Estabelecimento de meio de cultura e quantificação da germinação de grãos de pólen de cultivares de marmeleiro. Revista Brasileira de Fruticultura, v. 36, n. 2, p. 400-407, 2014. 